\title{
Bauxite deposits in Suriname: Geological context and resource development
}

\section{D.A. Monsels ${ }^{1,2}$}

1 Department of Geology and Mining, Anton de Kom University of Suriname. Email: dewany.monsels@uvs.edu

2 Department of Earth Sciences, Utrecht University

Manuscript received: 22 April 2015, accepted: 04 September 2015

\section{Abstract}

Bauxite, the raw material of aluminum, has been one of the economically vital natural resources for Suriname. Mining operations started about a century ago, and subsequent development of a refinery industry and hydro-electric power made Suriname one of the foremost bauxite and alumina producers worldwide for a long period of time. This paper presents a concise survey of the main geological attributes of its bauxite deposits and examines significant aspects in the development of mining in the country where alumina dominated the export revenues until a decade ago. The lateritic bauxite deposits are spread across the northern part of the country and developed on various parent rocks during Late Cretaceous-Early Tertiary times. Bauxites in the coastal lowlands formed on Cenozoic sedimentary deposits, whereas plateau bauxites originated on various crystalline rocks in inland regions of the Precambrian Guiana Shield. The composition of parent rocks and timing of bauxitisation point to a genetic correspondence with West African bauxites and a strong control of paleoclimatic conditions on the distribution and properties of bauxite in both regions. The more accessible bauxite deposits in the coastal lowlands are almost mined out, whereas the plateau bauxites have been extensively explored but have not been brought into production to date. For economic and environmental reasons, the future of the bauxite industry in Suriname is currently uncertain.

Keywords: bauxite, mining, Suriname

\section{Introduction}

Suriname has been one of the leading bauxite and alumina producers in the world for more than 90 years (Patterson et al., 1986; Aleva \& Wong, 1998; Gurmend, 2014). Its lateritic bauxite deposits are distributed in two major geographic areas with different origins, properties and exploitation histories. Coastal bauxites formed on sedimentary parent rocks in the coastal zone and have been mined since the early 20th century, whereas Plateau bauxites originated on metamorphic rocks in interior parts of the country and have not been productive to date. Bauxite deposits of economic interest occur in four districts (Fig. 1):

1. the Paranam-0nverdacht-Lelydorp district (Coastal), which includes the Lelydorp 1, Kankantrie and Para bauxite deposits
2. the Moengo-Ricanau-Jones district (Coastal) with the Coermotibo deepseated bauxite deposit

3. the Bakhuis district (Plateau) with the Bakhuis bauxite deposit

4. the Nassau district (Plateau), which encompasses the Nassau, Brownsberg, Lely bauxite and Wintiwaai laterite deposits.

Aleva \& Wong (1998) presented a detailed history of Suriname's bauxite. The first academic descriptions of bauxite in Suriname were written at the end of the 19th century. The Surinaamsche Bauxiet Maatschappij (SBM) was established in 1916 after the discovery of the Moengo bauxite hills in 1915 by the Pittsburg Reduction Company, later renamed the Aluminum Company of America (Alcoa). In 1939, the N.V. Billiton Maatschappij obtained a concession for bauxite exploration in the Para district, which led to the discovery of the 


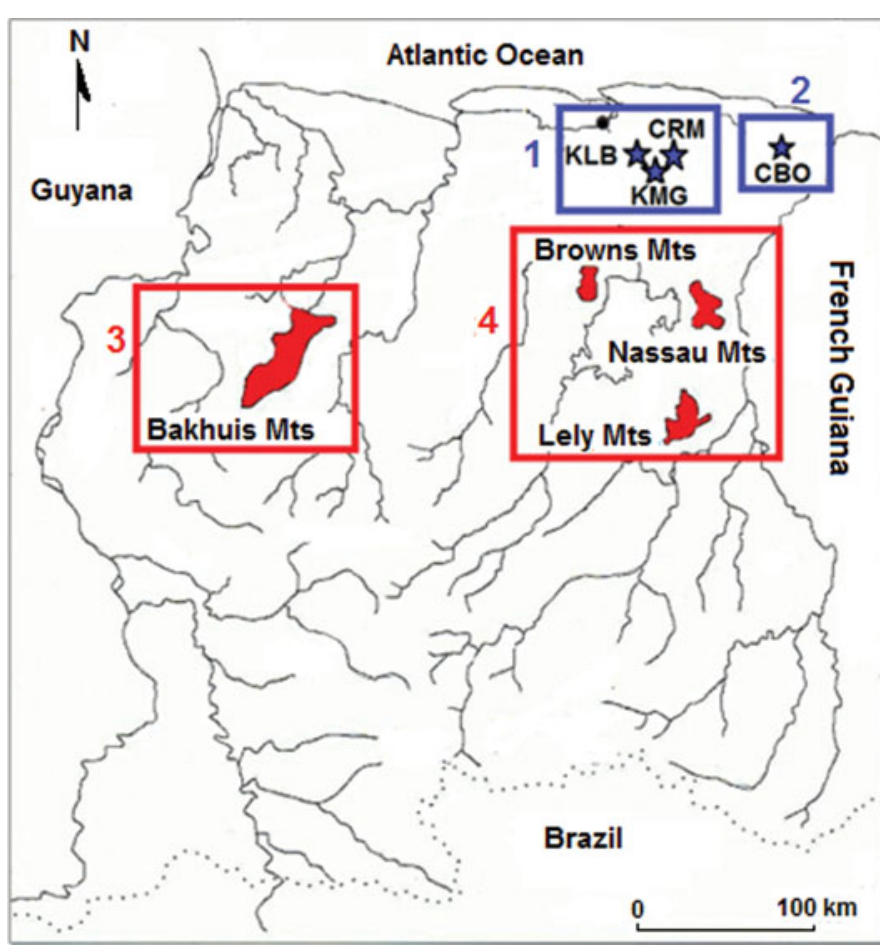

Fig. 1. Districts of coastal- and plateau-type deposits of bauxite in Suriname.

\section{LEGEND}

Bauxite districts

1. Paranam- Onverwacht-Lelydorp

2. Moengo- Ricanau- Jones

3. Bakhuis

4. Nassau

Coastal plain bauxite deposits

CBO : Coermotibo

CRM : Caramacca

KLB : Klaverblad

KMG: Kaaimangrasie

m Plateau bauxite deposit

River, creek

$\cdot . \cdot$ International borders
Onverdacht bauxite deposit. Suriname was one of the leading bauxite-producing countries in the world during the Second World War (1939-1945), which generated a boost in bauxite exploration and research on the local deposits. In 1941, the SBM opened the Paranam bauxite processing plant, named after the Para and Suriname Rivers bordering the mining concession areas. In 1958, SBM signed the Brokopondo Agreement with the Surinamese Government to create a fully integrated aluminum industry in the country, and became the Suriname Aluminum Company (Suralco). The most important objectives were the construction of a dam in the Suriname River and a hydro-electric power facility at Afobakka, and the establishment of an aluminum smelter and an alumina refinery at Paranam. The smelter operated from 1964 till 1999 and was dismantled one year later and the refinery closed in November 2015. In 1993, Suralco and Billiton signed a joint venture about mining and refining activities but Billiton halted its exploration and mining activities in Suriname in 2009, while Suralco is also reducing its activities. The Suralco is currently mining the remnants of some bauxite deposits in the Moengo area and the Lelydorp 1 deposit. The Lelydorp 1 mine has a total estimated reserve of $3.1 \mathrm{Mt}$ and was not considered of significant economic interest in the past (www.alcoa. com).

This paper presents a geological overview of Suriname's bauxite deposits, including a comparison with West African bauxites, and a summary of the exploitation history and economic impact for the country.

\section{General geological background of Surinamese bauxite deposits}

The bauxite deposits in South America are situated in four subprovinces of the Amazon Platform. The Guiana Shield subprovince includes bauxite deposits of Venezuela, Guyana, Suriname, French Guiana and Brazil (Fig. 2). The Coastal Plain subprovince contains bauxite deposits of Suriname and Guyana, while Brazilian bauxite deposits occur in the Guiana Shield, Amazon Basin and Central Brazil subprovinces.

Suriname is located on the Guiana Shield in the northeastern sector of South America. Precambrian rocks make up about $80 \%$ of the country, forming a crystalline basement, and the remaining $20 \%$ consists of Cretaceous to Recent sediments that were deposited along the northern fridge of the Guiana Shield (Coastal Plain) (Fig. 3a). The Guiana Shield stretches from Venezuela, Guyana, Suriname and French Guiana to Brazil (Fig. 2).

Five planation levels can be distinguished on the Guiana Shield (King et al., unpub.; Aleva, 1979; Bárdossy \& Aleva, 1990): (1) Summit Level, Jurassic to Cretaceous, (2) Main Aluminous Laterite Level, Early Tertiary, (3) Foothill Level, Oligocene to early Miocene, (4) Pediplane Level, Pliocene and (5) Valley Floor Level, Pleistocene to recent (Fig. 3b). The major bauxite and aluminous laterite horizons on the Guiana Shield are related to the well-developed and widespread Main Aluminous Laterite Level (Van Kersen, 1956; Wong 1989; Aleva \& Wong, 1998). 


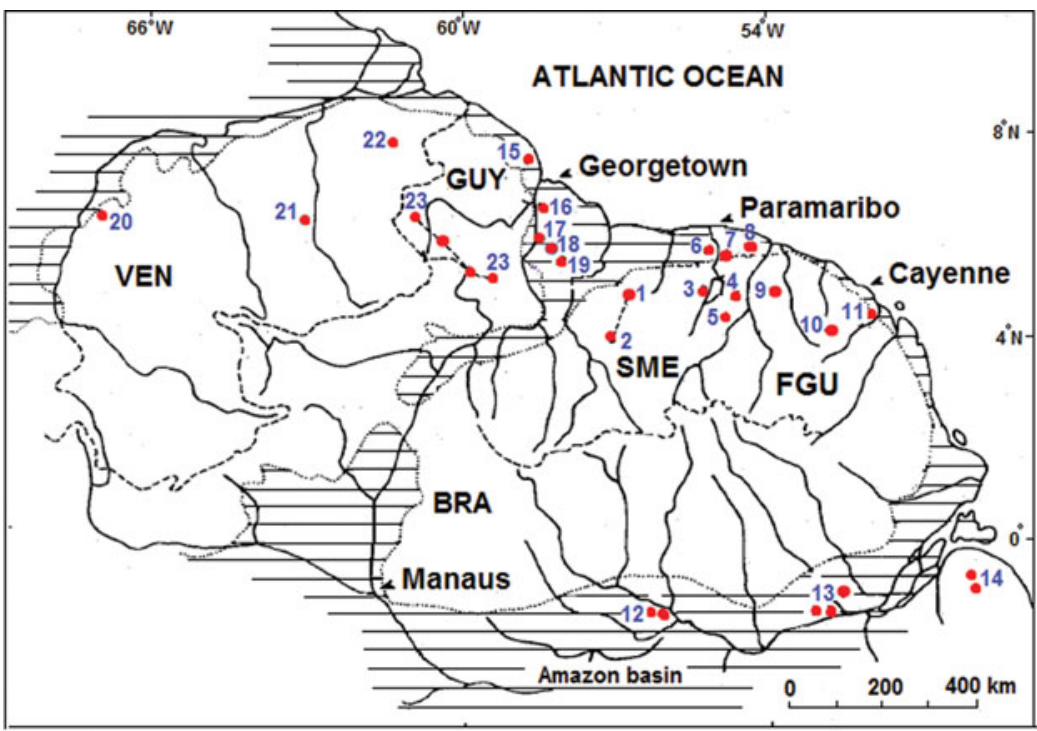

- Bauxite deposit

Phanerozoic

Precambrian

International boundary
BRA: Brazil

FGU: French Guiana

GUY: Guyana

VEN : Venezuela
LEGEND

SURINAME

1. Bakhuis Mts $\mathrm{N}$

2. Bakhuis Mts S

3. Brownsberg

4. Lely Mountains

5. Nassau Mountains

6. Paranam-Onverdacht-Lelydorp district

7. Succesor Mines

8. Moengo-Ricanau-Jones district

\section{FRENCH GUIANA}

9. Montagne Lucifer

10. Montagne Tortue

11. Montagnes de Kaw

BRAZIL

12. Trombetas district

13. Almeirim district

14. Paragominas district

GUYANA

15. Pomeroon

16. Essequibo

17. Mackenzie/Linden

18. Itumi

19. Kwakwani/Berbice

\section{VENEZUELA}

20. Pijiguaos

21. Los Guaicas

22. Nuria

23. Pakaraima Mountains

Fig. 2. Overview of the most important bauxite deposits of the Guiana Shield (Guiana Shield subprovince) with its Phanerzoic cover (Coastal Plain subprovince) (modified after Bárdossy \& Aleva, 1990).

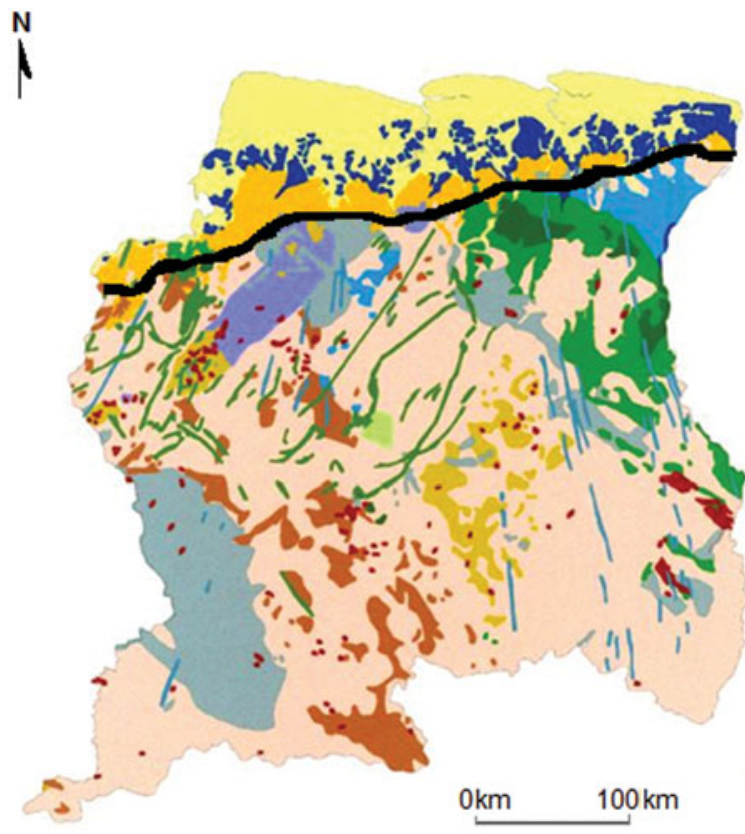

Holocene

$\square$ Clay, sand and shells

Pleistocene

- Clay, clayey sands and sand

Tertiary

$\square$ Coarse to fine white sands

Permo-Triassic

- Pigeonite dolerites

Middle Proterozoic

- Olivine and hyperstene dolerites

$\square$ Quartz arenite and conglomerate

Lower Proterozoic

- Biotite granites

口 Pyroxene granites

- Meta-rhyolites

- Meta-ultramafite

• Charnockitic granulite

- Meta-arenite, metavolcanic, metaconglomerate

- Metagreywacke, metavolcanic, phyllite

- Metabasalt and amphibolite

- Migmatitic gneiss and amphibolite

Break line between the coastal area (north) and the crystalline basement (south)

Fig. 3 A. Geological map of Suriname with boundary line between the sedimentary coastal area to the north and the crystalline basement to the South (modified after www.staatsolie.com and Kroonenberg et al., 2015); B. The planation levels, stratigraphy and pollen zones of Suriname (Van der Hammen \& Wijmstra, 1964; Wong, 1989; Bárdossy \& Aleva, 1990; Wong et al., 2009). 


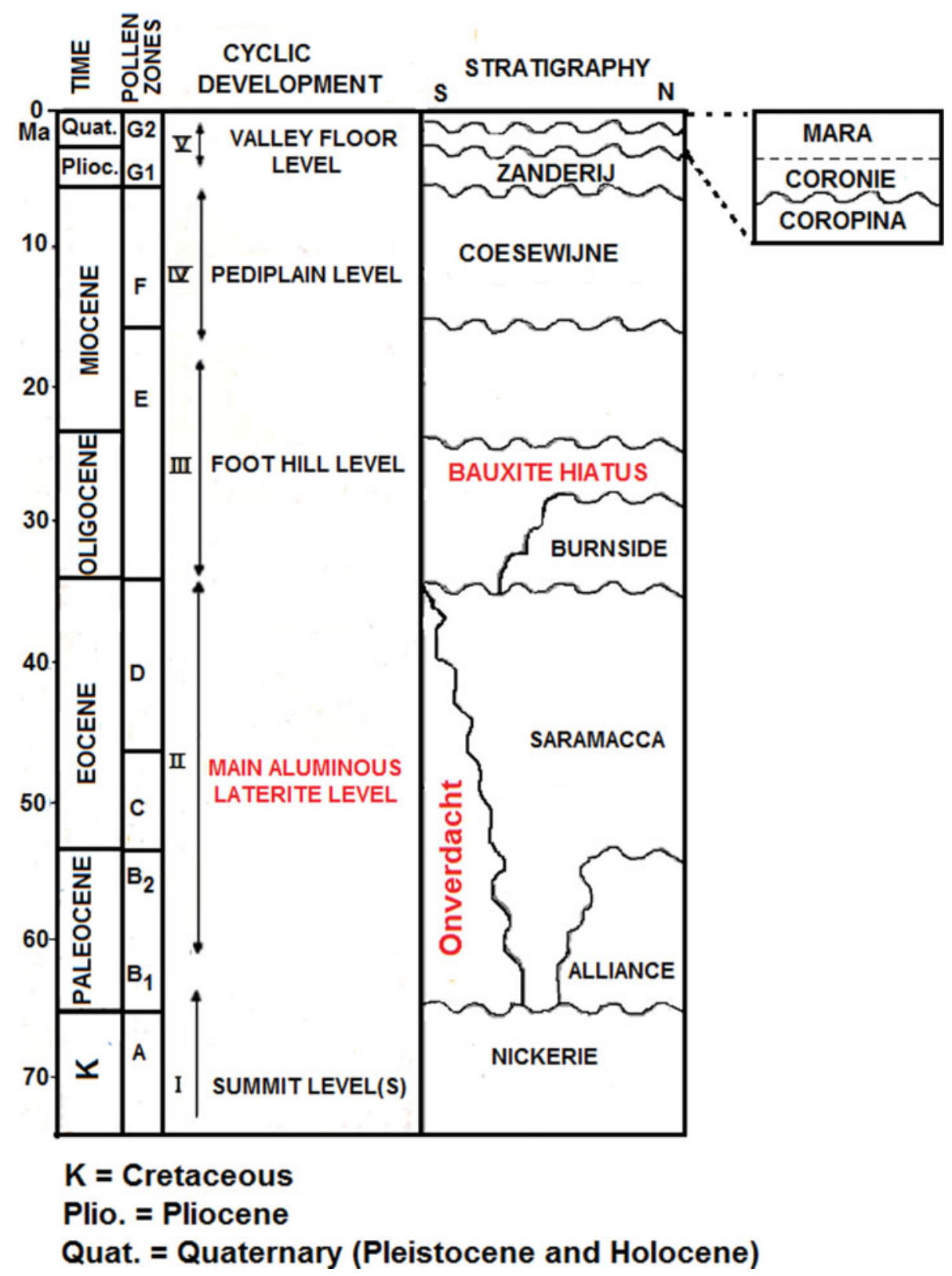

Fig. 3 Continued.

The age of this palaeosurface is well documented by Paleocene pollen from unconsolidated sediments (arkosic sands or kaolin) below, and Miocene sediments on the top of some of the major economic bauxite deposits in Guyana and Suriname (Van der Hammen et al., 1964). A long period of non-deposition during the Late Eocene to Oligocene is known as the 'Bauxite hiatus', during which intense weathering resulted in bauxitisation of the upper part of the Onverdacht Formation (Aleva \& Wong, 1998; Wong et al., 2009).

In Suriname, bauxite deposits formed on two different types of parent rock:

1 Sedimentary parent rocks in the coastal area (Coastal plain or Lowland bauxites).
The Coastal plain or Lowland bauxites formed at the expense of Cenozoic sediments in a bauxite belt running subparallel to the 'Old coastal plain', an accumulation of continental sediments that were deposited along a paleo-coastline during Early Cenozoic times (Valeton, 1983; Aleva \& Wong, 1998). As such, they belong to the global elongate belts of lateritic bauxite deposits in Cretaceous and Tertiary coastal plains, following Lower Tertiary shorelines of India and South America (Valeton, 1983). The Surinamese Coastal plain bauxites have an average thickness of $6 \mathrm{~m}$, a relatively low $\mathrm{Fe}_{2} \mathrm{O}_{3}$ content $(2 \%)$, a $\mathrm{SiO}_{2}$ content of $5-7 \%$ and an average available alumina content of more than $50 \%$. They can be subdivided into (i) surface bauxite deposits with less than $5 \mathrm{~m}$ overburden and (ii) buried or deep-seated bauxite deposits with up to $40 \mathrm{~m}$ overburden. 
Fig. 4 A. Distribution of the bauxite deposits in the Moengo-Ricanau-Jones district. Mined hills are highlighted in blue and the Coermotibo deposit in red (modified after Bárdossy \& Aleva, 1990); B. Crosssection through the bauxite deposits in the MoengoRicanau-Begi Gado-Jones district (modified after Bárdossy \& Aleva, 1990).

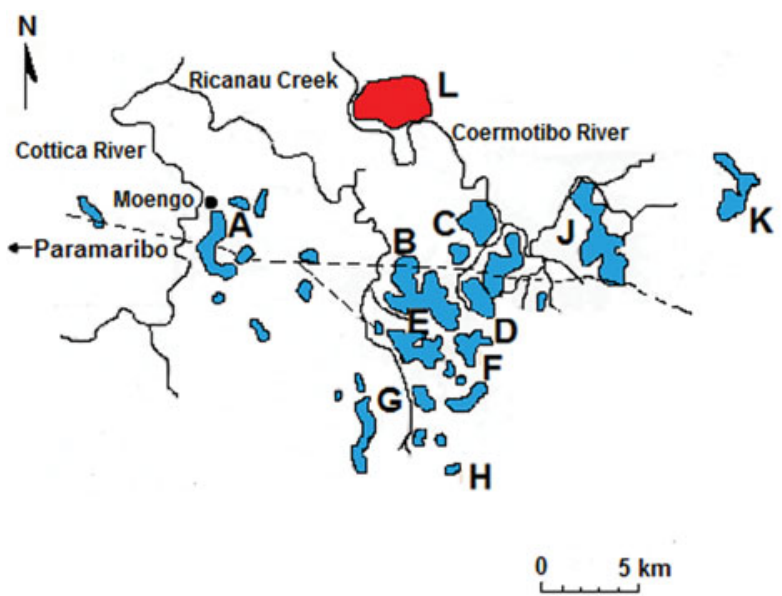

LEGEND

$A=$ Moengo Hill

$B=$ Ricanau Hill

C = Adjoema Hills

$\mathrm{D}=$ Madoekas Hill

E = Begi Gado Hill

$F=$ Tapira Hill

$\mathbf{G}=$ Jones Hills

$\mathrm{H}=$ Vijent Hill

$\mathrm{J}=$ Lobato Hills

$\mathrm{K}=$ Wane Hill

$\mathrm{L}=$ Coermotibo

- - - Roads

$\sim$ Rivers, creeks

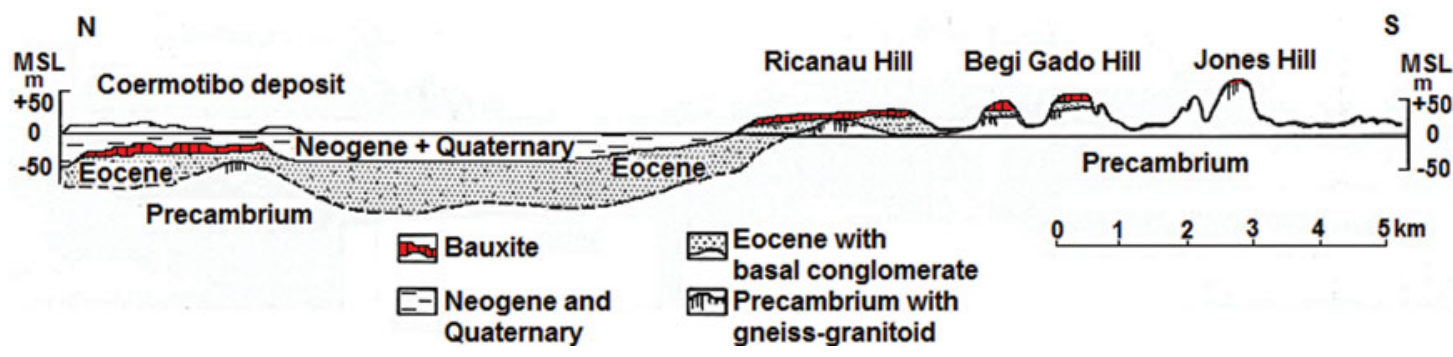

Fig. 4 Continued.

2 Crystalline parent rocks in the hinterland (Plateau or Highland bauxites).

The Plateau or Highland bauxites are mostly developed on intermediate to basic Precambrian igneous or metamorphic rocks of the Guiana Shield (Van Kersen, 1956; Bárdossy \& Aleva, 1990) (Fig. 1). They are found on plateaus (250-650 $\mathrm{m}$ above mean sea level) and have an average thickness of $4 \mathrm{~m}$ with little or no overburden $(<1 \mathrm{~m})$. The deposits are relatively $\mathrm{Fe}_{2} \mathrm{O}_{3}$ rich $(15-20 \%)$ and $\mathrm{SiO}_{2}$ poor (2-4\%), and have an average available alumina content of $45 \%$.

\section{Coastal plain deposits}

Coermotibo bauxite deposit The Coermotibo bauxite, named after the Coermotibo River, is a buried deposit belonging to the Moengo-Ricanau-Jones bauxite district, also known as the Moengo Group of deposits (Bárdossy \& Aleva, 1990) (Fig. 4A, B), located in the eastern part of the Guiana Coastal Plain at $5^{\circ} 32^{\prime} \mathrm{N}$, $54^{\circ} 18^{\prime} \mathrm{W}$. Here, a bauxite-capped plateau with a total surface area of approximately $20 \mathrm{~km}^{2}$ is split over 25 hills, varying in size between 0.03 and $7 \mathrm{~km}^{2}$. The bauxite layer is 3-6 m thick. All deposits but one (Coermotibo) stood out 25-70 m above the surrounding plain. The original geological reserve was approximately $127 \mathrm{Mt}$, and all of the exposed flat-topped bauxite hills are currently mined out except for the Coermotibo deposit, which has a reserve of 18-37 Mt. This bauxite deposit, with an overburden of approximately $40 \mathrm{~m}$, was discovered in June 1959 during reconnaissance core drilling along the Coermotibo River, but was neglected due to its high sulfide content and resilication (Bárdossy \& Aleva, 1990) despite a high average $\mathrm{Al}$ content $(51 \%)$ and a low average $\mathrm{Fe}_{2} \mathrm{O}_{3}$ content (4\%). The high sulfur content of the bauxite is linked to large quantities of marcasite $\left(\mathrm{FeS}_{2}\right)$. Much of the deposit is located beneath a swamp, which probably created the reducing conditions favourable for marcasite formation in the grey bauxite.

Successor Mines (Klaverblad, Kaaimangrasi, Caramacca) The Klaverblad, Kaaimangrasi, Caramacca bauxite deposits, better known as the Successor Mines, are located in the vicinity of the Paranam-0nverdacht-Lelydorp bauxite district $\left(5^{\circ} 20^{\prime} \mathrm{N}\right.$, $55^{\circ} 20^{\prime} \mathrm{W}$; Fig. 5A). Only five of the 13 deposits of the ParanamOnverdacht-Lelydorp bauxite district had outcrops (1, 3, 5, 6 and 7 in Fig. 5A), whereas the remaining deposits were covered by a thick packet of sediments. Most the bauxite-capped hills are underlain by Early Eocene and Paleocene sediments. Exploration of this bauxite district started in 1939, while mining commenced in 1941. The district originally consisted of 13 bauxite deposits, several of which are currently mined out. The original reserves of $100 \mathrm{Mt}$ were based on a cutoff grade of $\mathrm{Fe}_{2} \mathrm{O}_{3}$ $<30 \%$ and $\mathrm{TSiO}_{2}<15 \%$.

The Klaverblad (KLB), Kaaimangrasie (KMG) and Caramacca (CRM) deposits were discovered during the Brokopondo bauxite exploration campaign in the early 1960s and 1970s (Fig. 5B). The overburden at KLB was approximately $15 \mathrm{~m}$ thick and 

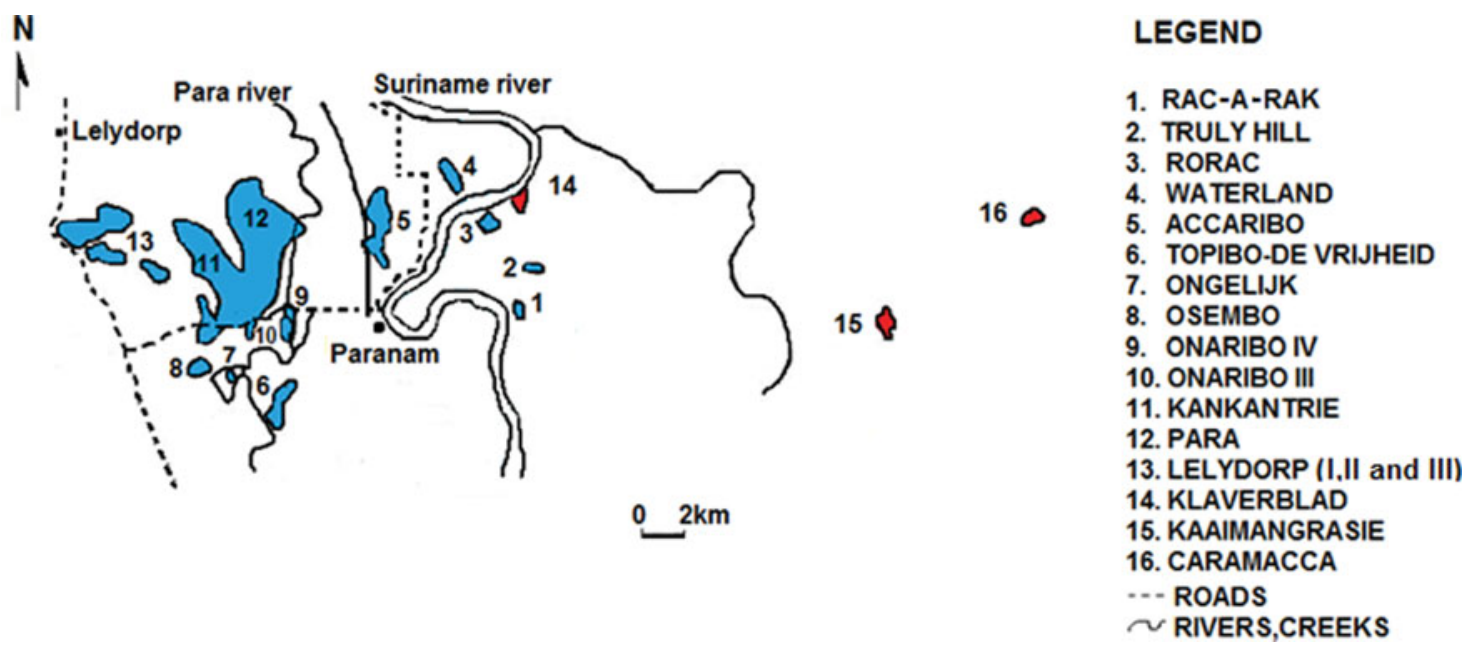

Fig. 5 A. Location of the original bauxite deposits in the Paranam-Onverdacht-Lelydorp bauxite district (indicated in blue). The Successor Mines are highlighted in red (modified after Bárdossy \& Aleva, 1990); B. Schematic relative position of the bauxite deposits of Successor Mines in a south-north section; C. Weathering profile in the Klaverblad deposit.

S N

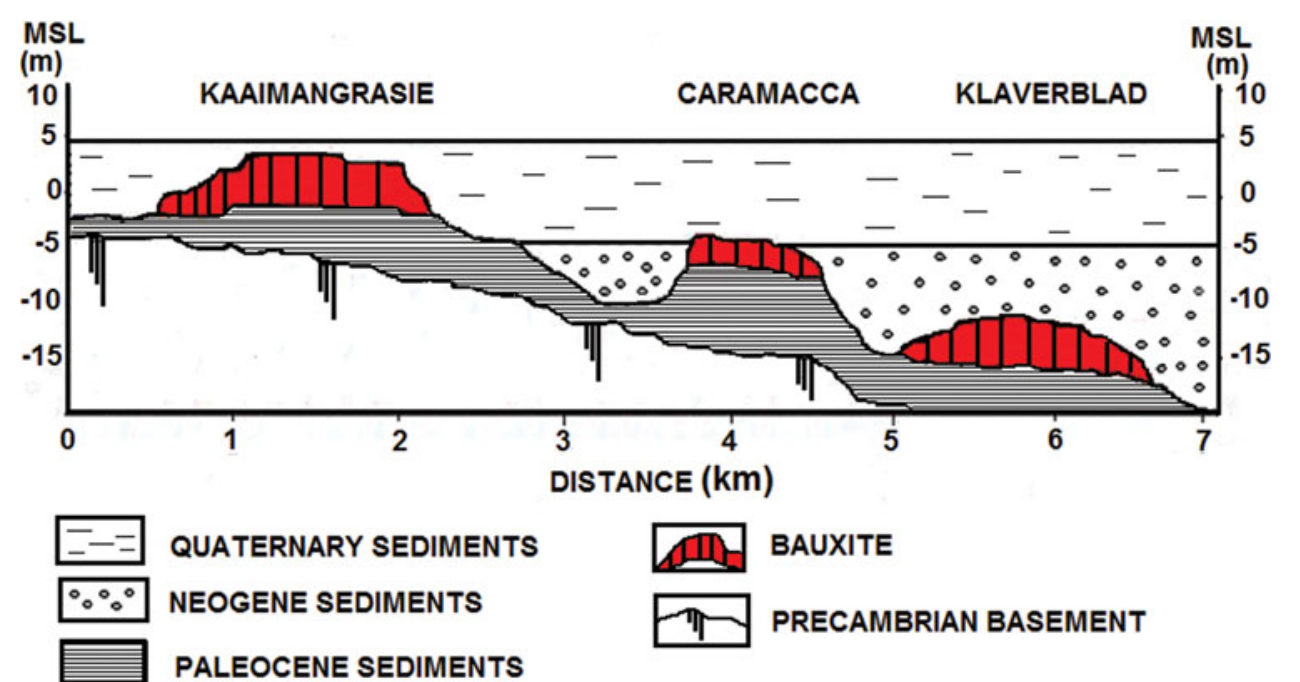

Fig. 5 Continued.

consisted of Neogene and Quaternary sediments, while the sedimentary cover of the KMG and CRM deposits consisted of Quaternary sediments with thicknesses of 4 and $9 \mathrm{~m}$, respectively (Successor Mines Project feasibility study, unpub.) (Fig. 5B, C). Mining of the Successor Mines started in 2004, and the remnants of the Caramacca deposit were mined in 2015. The initial reserve of the Successor Mines was $16 \mathrm{Mt}$.

\section{Plateau deposits}

Bakhuis Mountains The Bakhuis Mountains form a chain of strongly dissected plateaus in the district of Sipaliwini $\left(4^{\circ} 45^{\prime} \mathrm{N}\right.$, $\left.56^{\circ} 40^{\prime} \mathrm{W}\right)$. They are an expression of a $25 \mathrm{~km}$ wide and $95 \mathrm{~km}$ long NE-SW striking horst (Fig. 2a) (Kroonenberg \& de Roever, 1975; Kroonenberg, 1976). It covers an area of approximately
$2400 \mathrm{~km}^{2}$ (Fig. 6A). Hilltops reach a height of approximately $+480 \mathrm{~m}$ MSL. The climate is tropical humid with an average temperature of $27.5^{\circ} \mathrm{C}$ and $1700-2200 \mathrm{~mm}$ of rainfall, divided over a long and a short rainy season. The basement of the Bakhuis Mountains consists of high-grade metamorphic rocks which includes banded (mafic and intermediate) granulites, sillimanite gneisses with mafic and felsic intrusive bodies (Fig. 2a) (De Roever et al., 1976, 2003; Klaver et al., 2015; Kroonenberg et al., 2015). The banded granulites and sillimanite gneisses underwent high-grade (UHT) metamorphism between 2.055 and 2.072 Ga (de Roever et al., 2003). The charnockite intrusions in the southwest part of the horst are formed at 1984.4 to 1992.5 Ma (Klaver et al., 2015).

Variable compositions of bauxite weathering profiles reflect the large diversity of parent rocks (Aleva \& Hilversum, 1984) 


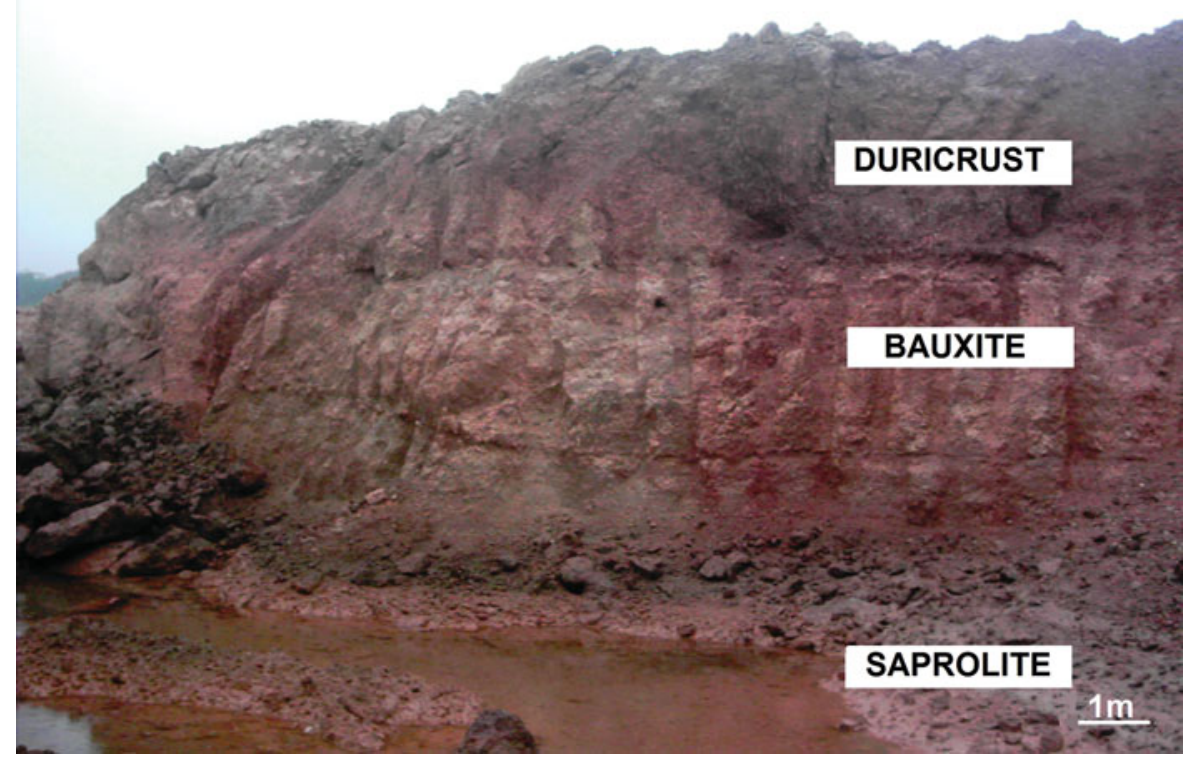

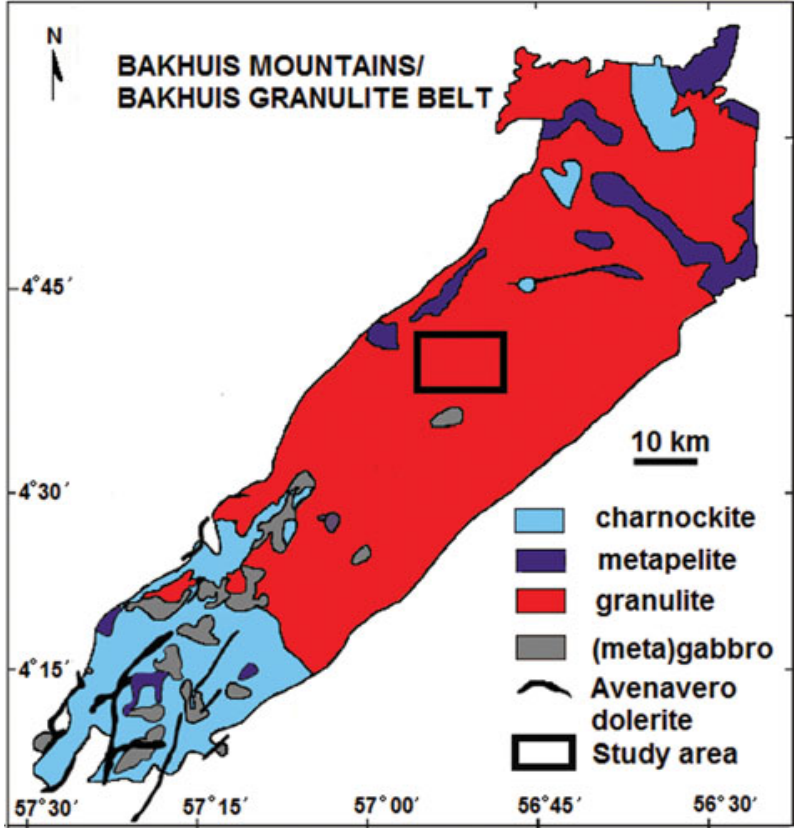

Fig. 6 A. Geological map of the Bakhuis Mountains horst (modified after Klaver et al., 2015); B. Approximately $2.4 \mathrm{~km}$ long west-east profile in Area 10. Note the highly variable grade and ore thickness in the horizontal direction (modified after Janssen, 1963).

(Fig. 6B), which, together with different drainage conditions, is also responsible for the variable thicknesses of the bauxite body. Locally, lenses of kaolinite-rich material occur within the bauxite horizon, and lenses and boulders of bauxite material within the kaolinitic saprolite (Fig. 6B) (Pollack, 1981;
Aleva \& Hilversum, 1984). Exposures of fresh bedrock and boulders along slopes, hill tops, creek beds and within the lateritic bauxite body are common. The bauxite resources of the Bakhuis Mountain are estimated to be larger than $500 \mathrm{Mt}$ and contain an average of $34 \%$ available alumina and $2 \%$ reactive silica (www.bauxietinstituut.com).

Nassau Mountains The Nassau Mountains in the Marowijne district in northeast Suriname $\left(4^{\circ} 46^{\prime}-4^{\circ} 54^{\prime} \mathrm{N}, 54^{\circ} 30^{\prime}-54^{\circ} 38^{\prime} \mathrm{W}\right)$ form an isolated, U-shaped mountain ridge $\left(20 \times 20 \mathrm{~km}^{2}\right)$, which is bordered by the Professor W.J. Van Blommenstein Lake to the west and the Marowijne River to the East (Fig. 7). The ridge comprises four steep-sided, laterite-capped plateaus (AD) at elevations between 500 and $564 \mathrm{~m}$ above mean sea level (Alonso \& Mol, 2007). The mountains receive some of the highest rainfall in the country $(2750-3000 \mathrm{~mm} /$ year, even more on the plateaus) due to orographic effects and mist interception (Alonso \& Mol, 2007 and references therein).

The Nassau Mountains and surrounding areas belong to the NW-SE striking Trans-Amazonian Marowijne Greenstone Belt with zircon ages between 2.26 and 2.10 Ga (Delor et al., 2003; Klaver et al., 2015; Kroonenberg et al., 2015). The Nassau Mountain contains rocks from the Paramaka formation, which consists of metabasalts, metagabbro, meta-andesites, meta-cherts and other intermediate and felsic metavolcanic rocks (De Vletter, 1984; De Vletter et al., 1998; Bárdossy \& Aleva, 1990).

The presence of pure bauxite in the midst of highly hematitic laterite was discovered in 1918 by Douglas and Beems (Doeve, unpub.). The deposit belongs to the Nassau bauxite district, which also includes other bauxite-laterite-covered high 
W

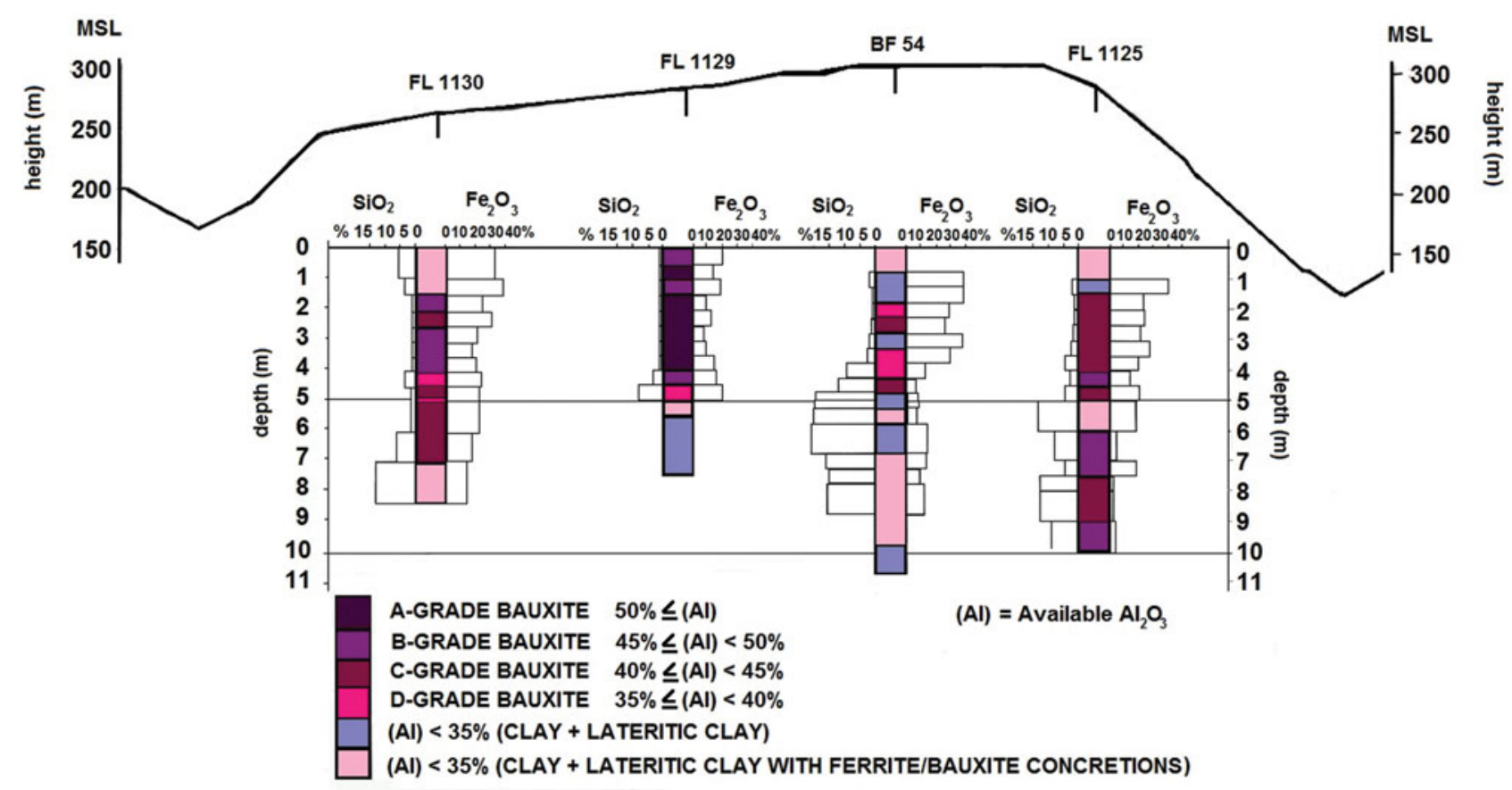

Fig. 6 Continued.

plateaus (Brownsberg, Wintiwaai and Lely Mountains) in eastern Suriname (Bárdossy \& Aleva 1990, and references therein). These mountains are tentatively attributed to an early Tertiary surface (King et al., unpub.).

It has been estimated that the Nassau deposit contains about 40 million dry tonnes of bauxite, most of which is located in c. $1.7 \mathrm{~m}$ thick lateritic deposits below an overburden with an average thickness of $1.5 \mathrm{~m}$. The most promising mining areas are Plateaus A and C (Fig. 7). The Nassau deposit would be sufficient to supply the Paranam refinery with 4.2 million dry tonnes per year during 8 years (Van den Bergh, 2011). Current obstacles to extract this deposit are the absence of infrastructure to transport the bauxite to Paranam, and environmental concerns about the presence of critically endangered endemic species of catfishes and frogs in these mountains (Ouboter et al., 2007; Alonso \& Mol, 2007).

\section{Comparison of Guiana Shield (Surinamese) and West African bauxite deposits}

Large parts of South America and Africa are covered by a thick lateritic mantle (Tardy et al., 1991; Tardy, 1997; Fig. 8), which includes bauxites, ferricretes and nodular soils. The continents were separated in Cretaceous times during the breakup of Pangea (Pletsch et al., 2001). There are conspicuous similarities and differences between the Surinamese and West African bauxite deposits.

\section{Similarities and differences between Surinamese and West African bauxites}

1 Most bauxites on both sides of the Atlantic are PaleoceneEocene-Oligocene in age (Prasad, 1983; Bárdossy \& Aleva, 1990; Théveniaut \& Freyssinet, 2002; Chardon et al., 2006) and formed during a bauxitisation phase when conditions were favourable worldwide (Fig. 9).

2 In both cases the bauxites are related to planation surfaces, in Suriname to the Main Aluminous Laterite Level (Fig. 3B) and in West Africa to the African Level (King et al., unpub.; Aleva, 1994; Wong et al., 1998).

3 The plateau bauxites of Suriname and most of the West African countries have a metamorphic Proterozic parent rock (Prasad, 1983; Mutakyahwa et al., 2003; Chardon et al., 2006).

4 An important difference is the mineralogical signature of the bauxites, as the Surinamese bauxites are dominantly gibbsitic with traces of boehmite in some deposits (e.g. in the Nassau deposit), while the West African bauxites are also characterised by high gibbsite contents but generally have higher boehmite contents (Fig. 10). The boehmite content in the West African bauxite deposits increases northwards towards the warmer and more arid conditions of the Sahara (Tardy et al., 1991). 


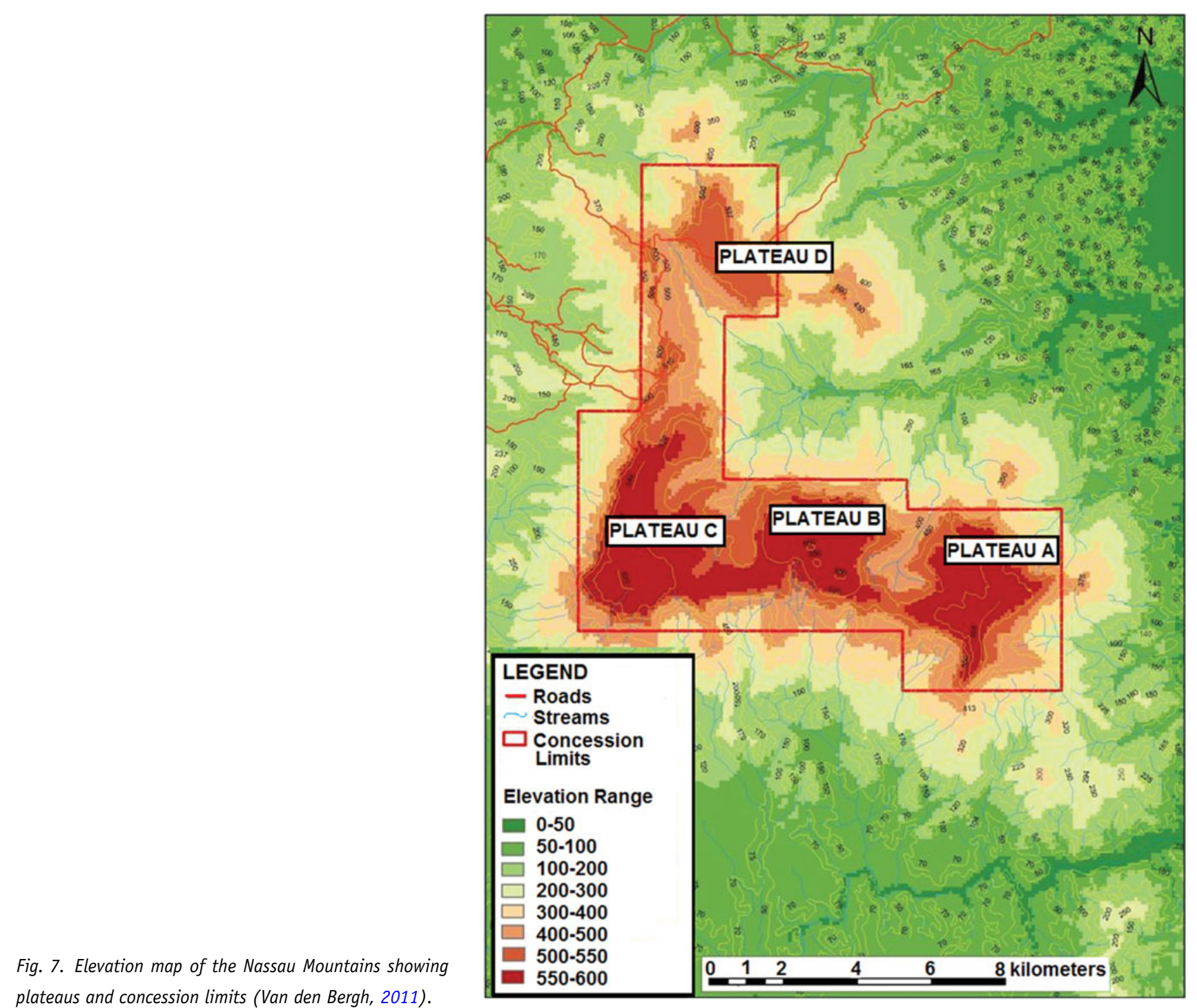

plateaus and concession limits (Van den Bergh, 2011).

5 Mineralogical changes from gibbsite and goethite into boehmite and hematite are accompanied by the formation of nodular and pisolitic structures and induration of ferricretes and bauxites (Bárdossy \& Aleva, 1990; Tardy et al., 1991). This explains the frequent pisolitic texture of the West African bauxites compared to the generally massive texture of the Surinamese bauxites.

\section{Climate control on bauxite distribution and mineralogy}

The most favourable climatic conditions for bauxite formation are in tropical to humid subtropical zones with a mean annual temperature higher than $20^{\circ} \mathrm{C}$, a mean annual rainfall of more than $1700 \mathrm{~mm}$ and less than 4 months of dry season, which are currently located in a latitudinal belt approximately between $300^{\circ} \mathrm{N}$ and $300^{\circ} \mathrm{S}$ (McFarlane, 1983; Valeton, 1983; Bárdossy \& Aleva, 1990). Bauxite deposits worldwide have formed in hot and humid (paleo-)tropical or (paleo-)equatorial regions since Devonian times (Valeton, 1972; Patterson et al., 1986; Bárdossy \& Aleva, 1990; Tardy et al., 1991; Tardy, 1997). Bauxites have been retained on separate fragments of post-Gondwanan surface in South America, Africa and India, i.e. in the present hot and humid tropical zone (Prasad, 1983).

West African bauxites in humid zones (Guinea, Nigeria and Cameroon) and in drier areas (Burkina Faso) are considered to have formed during Jurassic, Cretaceous or Eocene times, when conditions were generally more humid than today (Tardy et al., 1991).

Contrasting chemical, mineralogical and textural characteristics of laterites on the African and South American continents can be attributed to latitudinal differences in present-day 

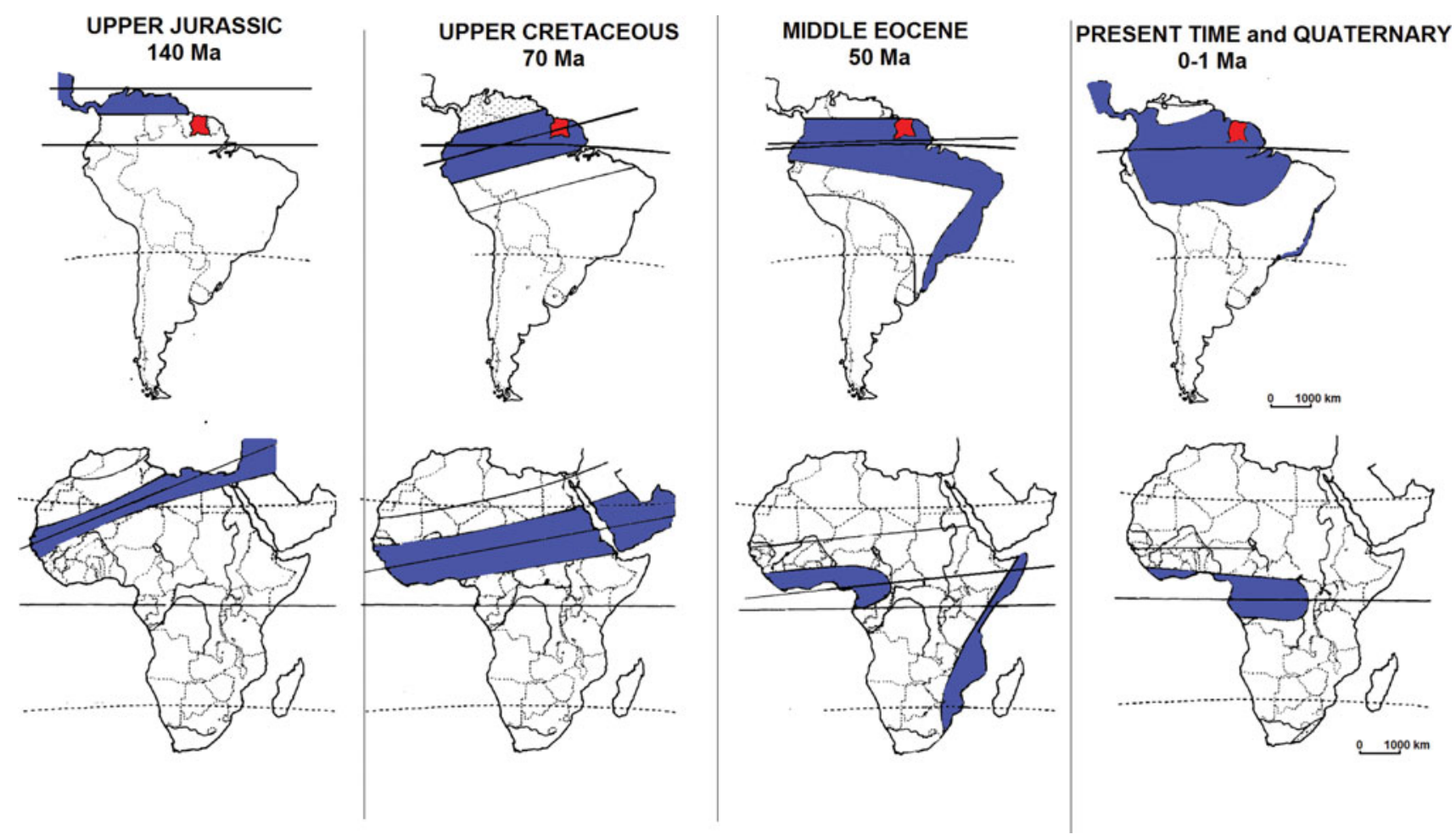

Fig. 8. Distribution of bauxite in South America and Africa (depicted in blue) since Jurassic times (modified after Tardy et al., 1991). The location of Suriname is highlighted in red.

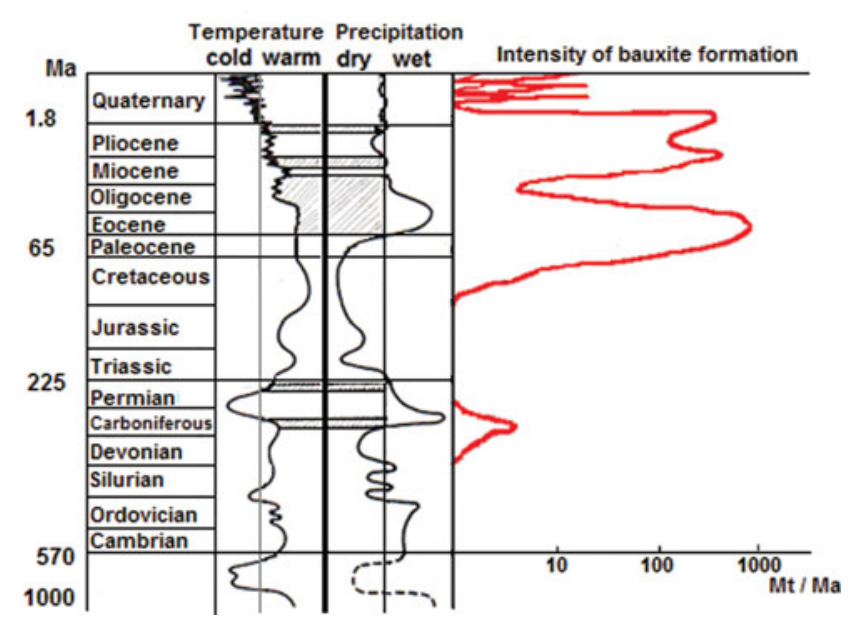

Fig. 9. Periods of worldwide lateritic bauxite formation (Bárdossy \& Aleva, 1990).

climates as well as to separate paleoclimatic histories since the opening of the Atlantic 0cean (Tardy et al., 1991). From Jurassic to present times, the previously arid climates of South America became progressively more humid whilst the formerly humid climates of West Africa progressively became more arid. In Africa the development of ferricretes gradually decreased northwards, as humidity decreased. The Saharan influence increased and altitude increased. Fossil ferricretes occur in the Sahara, providing evidence for more humid ancient climates than today (Tardy et al., 1991 and references therein).

This mineralogical composition of bauxite can also be controlled by climate, as boehmite and hematite (dehydrated minerals) are often associated with relatively arid climates, while gibbsite and goethite (hydrated minerals) are related to constantly humid climates (Bárdossy \& Aleva, 1990; Tardy, 1997).

During the paleoclimatic history of West Africa, boehmite formation could be considered as secondary and contemporaneous to hematite (Tardy et al., 1991). In tropical climates with a marked dry season and relatively high temperatures, humidity is usually sufficient to induce a strong weathering during rainfall but the temporary aridity of the dry season results in dehydration of gibbsite and goethite into boehmite and hematite, respectively (Tardy et al., 1991; Tardy, 1997).

\section{Bauxite and alumina production in Suriname and the economic outlook}

Bauxite has been one of the most important sources of income for Suriname since 1930 (Aleva \& Wong, 1998; www.bauxietinstituut.com). Bauxite was exported as a raw 


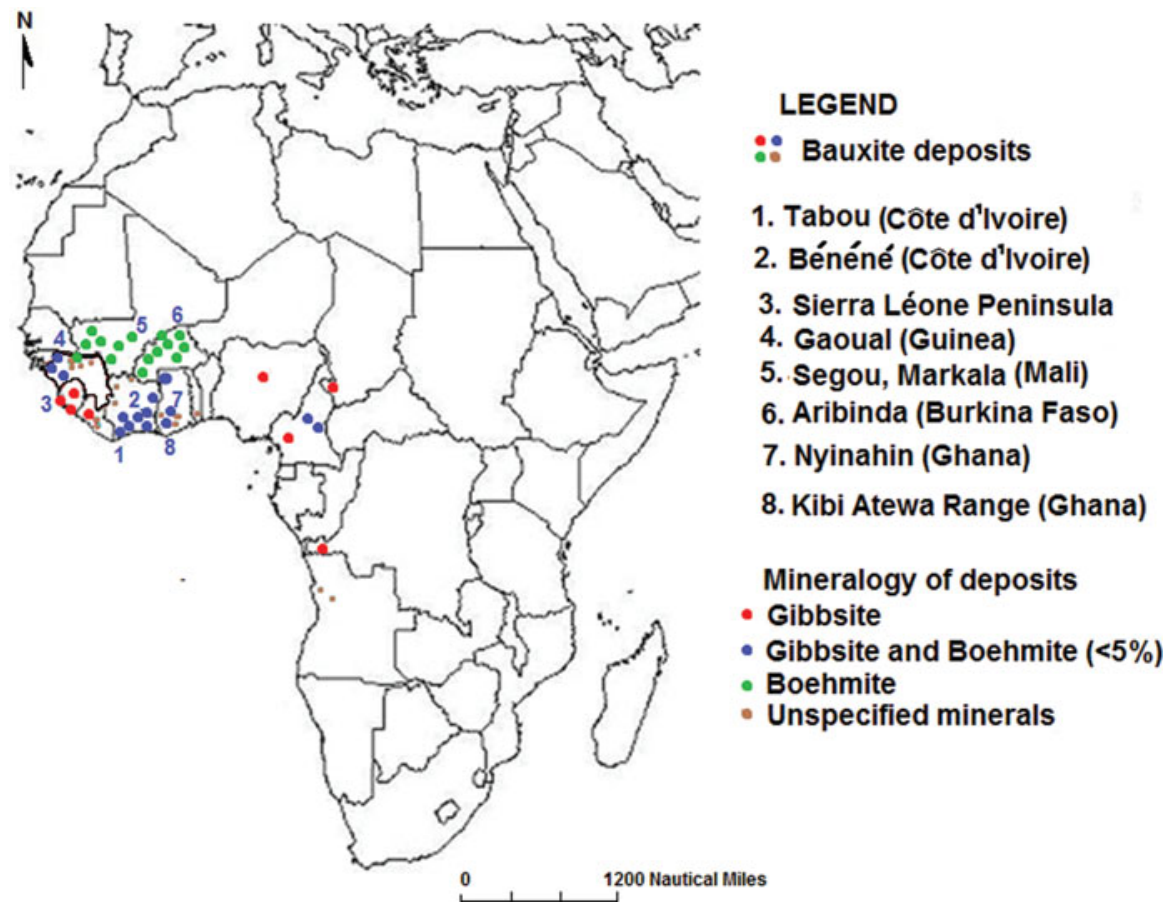

African bauxites (based on data from Tardy, 1997).

REAL TOTAL EXPORTS \& REAL GROSS DOMESTIC PRODUCT

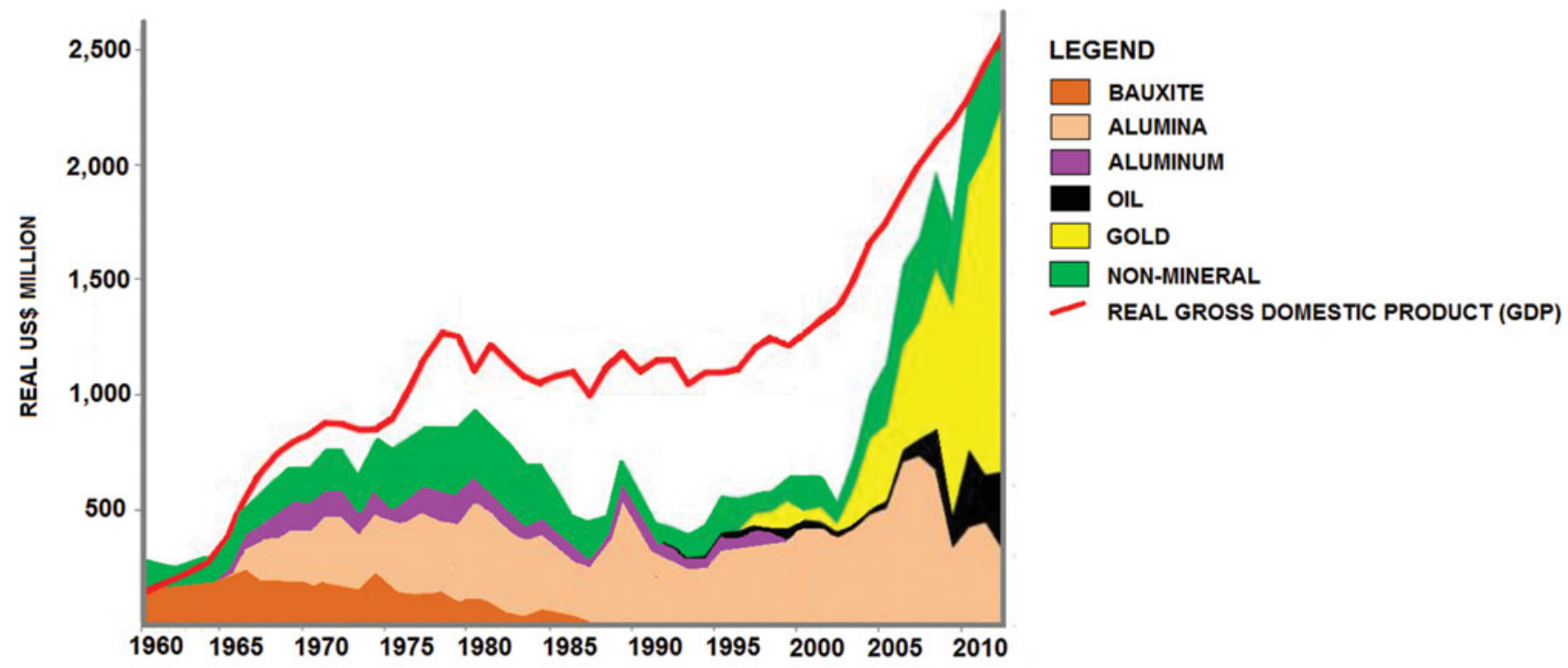

Fig. 11 A. Real total export of commodities and real gross domestic product of Suriname, 1960-2010. B. Mining export between 2007 and 2013 expressed in millions of US dollars. Modified from Hoefdraad, G., 2014.

material till 1985, whereas the export of aluminum as an end product started in 1965 and ceased in 2000. The export of alumina, the intermediate refinery product of bauxite, also commenced in 1965 and ceased in 2015 (Fig. 11A). The leading geological commodities (alumina, gold and petroleum) contribute $95 \%$ to the total export and accounted for $35 \%$ of the country's revenues, making the Surinamese economy highly vulnerable to market price volatility (Fig. 11A). The bauxite sector in Suri- name lost its position as the main foreign exchange earner in 2004. Mining activities were significantly affected by the global economic recession that started in 2008. Bauxite revenues declined (Fig. 11B) following a drop in alumina demand and market prices (Central Bank of Suriname (www.cbvs.sr), 2015).

Most of the bauxite deposits were discovered during the early 1950s when the Surinamese government carried out 


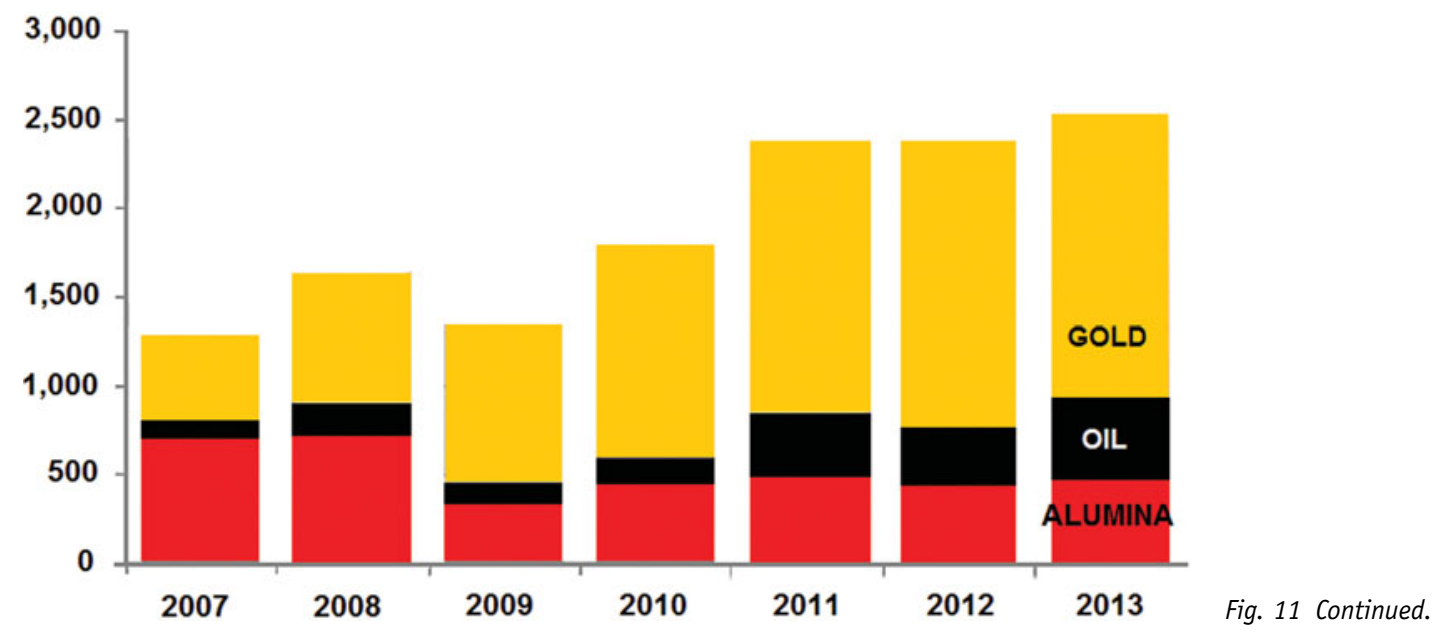

extensive exploration programmes across the country. 0ther Surinamese bauxite deposits that had already been discovered have not been mined to date because ore grade and other economic parameters did not allow a profitable extraction. These unexploited bauxite deposits have a total reserve of $580 \mathrm{Mt}$ (www.bauxietinstituut.com; Lee Bray, 2015).

The future economic potential of bauxite in Suriname is uncertain and will be determined by the quality and size of the reserves, geological conditions, available production technology, targeted locations in relation to transport facilities, world market price and political factors. Existing Surinamese bauxite deposits have not been mined yet for different reasons. The Coermotibo deposit has not been economically attractive due to the high sulfur content in the bauxite and the $40-\mathrm{m}$ thick overburden. The heterogeneous properties of the bauxite within the Bakhuis and Nassau bauxite deposits will make it necessary to drill a very close-spaced grid for mine planning. The remote location of the Nassau Mountains is also an economic and strategic problem. Political and economic factors have hampered mining of the Bakhuis deposit. A final and most sensitive obstacle is the environmental impact, as the Nassau Mountains have a unique flora and fauna, including critically endangered endemic species (Ouboter et al., 2007; Bánki et al., 2008; Alonso \& Mol, 2007).

\section{Concluding remarks}

The lateritic bauxites of Suriname are derived from a variety of sedimentary and crystalline parent rocks. A diversity of geological conditions has yielded a multitude of bauxite deposits with variable quality, grade and accessibility, which are scattered across Cenozoic sediments of the coastal lowlands and Precambrian basement rocks of the interior highlands. During a century-long mining history and associated refining operations, the country became one of the world's leading producers of bauxite, alumina and aluminum. The Al-based mineral commodities were a central pillar of Suriname's economy for many decades. At present, the high-grade deposits of the coastal lowlands are virtually mined out and significant reserves are restricted to occurrences in the more remote highlands. Despite a continuous growth of the annual global production of primary aluminum in recent years, Suriname's production of alumina is currently in decline, largely due to unfavourable economic conditions. The future of the bauxite industry in Suriname is therefore uncertain.

\section{Acknowledgements}

This work was supported by the Suriname Environmental and Mining Foundation (SEMIF).The author would like to thank Manfred van Bergen and two anonymous reviewers for their valuable comments and suggestions to improve this manuscript.

\section{References}

Aleva, G., 1979. Bauxites and other duricrusts in Suriname: A review. Geologie en Mijnbouw 58: 321-336.

Aleva, G., 1994. Laterites. Concepts, geology, morphology and chemistry. ISRIC (Wageningen): $169 \mathrm{pp}$.

Aleva, G. \& Hilversum, A., 1984. West Suriname: known deposits and potential. In: Jacob Jr., L. (ed.): Bauxite: Proceedings of 1984 Bauxite symposium (Los Angeles). American Institute of Mining Metallurgical and Petroleum Engineers (New York): 319-348.

Aleva, G. \& Wong, Th.E, 1998. The history of bauxite exploration and mining in Suriname. In: The history of earth sciences in Suriname. Royal Netherlands Academy of Arts and Sciences \& Netherlands Institute of Applied Geoscience. TN0: 275-310.

Alonso, L. \& Mol, J. (eds), 2007. A rapid biological assessment of the Lely and Nassau Plateaus, Suriname (with additional information on the Brownsberg 
Plateau). RAP Bulletin Assessment 43. Conservation International (Arlington): $279 \mathrm{pp}$.

Bánki, 0., Ter Steege, H., Jansen-Jacobs, M. \& Raghoenandan, U., 2008. Plant diversity of the Nassau Mountains, Suriname; Report of the 2003 Expedition. NHN-Utrecht branch. University of Utrecht (Utrecht), BBS, Anton de Kom University of Suriname (Paramaribo): 1-52.

Bárdossy, G. \& Aleva, G., 1990. Lateritic bauxites. Developments in Economic Geology 27: 569.

Chardon, D., Chevilotte, V., Beauvais, A., Grandin, G. \& Boulangé, B., 2006. Planation, bauxites and epirogeny; one or two paleosurfaces on the West African margin. Geomorphology 82: 273-282.

Delor, C., De Roever, E., Lafon, J., Lahondere, D., Rossi, P., Cocherie, A., Guerrot, C. \& Potrel, A., 2003. The Bakhuis ultrahigh-temperature granulite belt (Suriname): II. Implication for late Transamazonian crustal stretching in a revised Guiana Shield framework. Geology of France and surrounding area (France), No. 2-3-4: 207-231.

De Roever, E., Kieft, C., Murray, E., Klein, E. \& Drucker, W., 1976. Surinamite, a new $\mathrm{Mg}$-Al silicate from the Bakhuis Mountains, western Surinam: I. Description, occurrence and conditions of formation. American Mineralogist 61: 193-199.

De Roever, E., Lafon, J., Delor, C., Cocherie, A., Rossi, P., Guerrot, C. \& Potrel, A., 2003. The Bakhuis ultrahigh-temperature granulite belt (Suriname); 1. Petrological and geochronological evidence for a counterclock wise P-T path at 2.07-2.05 GA. Géologie de la France 2-3-4: 175205.

De Vletter, D., 1984: Economic geology and mineral potential of Suriname. In: De Vletter, D.R (ed.): Geology of Suriname 8. Mededelingen Geologische Mijnbouwkundige Dienst Suriname 27: 91-129.

De Vletter, D., Aleva, G. \& Kroonenberg, S., 1998. Research into the Precambrian of Suriname. In: Wong Th.E., De Vletter D., Krook L., Zonneveld J. \& van Loon A. (eds): The History of Earth Sciences in Suriname. Royal Netherlands Academy of Arts and Sciences \& Netherlands Institute of Applied Geoscience, TNO (Amsterdam): 15-64.

Gurmendi, A., 2014. The mineral industries of French Guiana, Guyana, and Suriname. In: US Geological Survey Minerals Yearbook 2012: 10.610.9 .

Hoefdraad, G., 2014. Leading Sectors of Suriname; The impact of Mining, Agriculture and Tourism activities on the Economy, 1970-2012, Central Bank of Suriname (CBVS) (Paramaribo): $147 \mathrm{pp}$.

Janssen, J., 1963. Reconnaissance exploration for bauxite in the AdampadaKabalebo Area 1961-1963. Internal report, Geologische Mijnbouwkundige Dienst (Paramaribo): $45 \mathrm{pp}$.

Klaver, M., De Roever, E., Nanne, J., Mason, P. \& Davies, G., 2015. Charnockites and UHT metamorphism in the Bakhuis Granulite Belt, western Suriname; Evidence for two separate UHT events. Precambrian Research 262: 1-19.

Kroonenberg, S., 1976. Amphibolite facies and granulite facies metamorphism in the Coeroenie Lucie Area, SW Suriname. Mededelingen Geologische Mijnbouwkundige Dienst van Suriname 25: 109-209.

Kroonenberg, S. \& De Roever, E., 1975. Dumortierite in cordierite pseudomorphs and in shear zones in high grade metamorphic rocks from western Suriname. Mededelingen Geologische Mijnbouwkundige Dienst Suriname 23: 255259.
Kroonenberg, S., De Roever, E., Fraga, L., Reis, N., Faraco, M., Lafon, J., Cordani, U. \& Wong, Th, 2015. Paleoproterozoic evolution of the Guiana Shiled in Suriname: A revised model. Netherlands Journal of Geoscience.

Lee Bray, E., 2015. US Geological Survey Mineral commodity summaries, Aluminum 2015: 16-17.

McFarlane, M., 1983. Laterites. In: Goudi, A. \& Pye, K. (eds): Chemical sediments and geomorphology: precipitates and residua in the near surface environment. Academic Press (London): 7-59.

Mutakyahwa, M., Ikingura, J. \& Mruma, A., 2003. Geology and geochemistry of bauxite deposits in Lushoto District, Usambara Mountains, Tanzania. Journal of African Earth Sciences 36: 357-369.

Ouboter, P., Jairam, R. \& Wan Tong, You, 2007. Additional records of amphibians from the Nassau Mountains, Suriname. In: Alonso, L. and Mol, J. (eds): A rapid biological assessment of the Lely and Nassau Plateaus, Suriname (with additional information on the Brownsberg Plateau). RAP Bulletin of Biological Assessment 43. Conservation International (Arlington): 128129.

Patterson, S., Kurtz, H., Olson, J. \& Neeley, C., 1986. World bauxite resources, geology and resources of aluminium. US Geological Survey professional paper 1076-B. US Government Printing Office (Washington): 125 pp.

Pletsch, T., Erbacher, J., Holborn, A., Kuhnt, W., Moullade, M., ObohIkuenobede, F., Söding, E. \& Wagner, T., 2001. Cretaceous separation of Africa and South America; the view from the West African margin (ODP Leg 159). Journal of South American Earth Sciences 14: 147-174.

Pollack, H., 1981. Bauxites and laterites of the Bakhuis Mountain Zone, western Suriname; a general description with emphasis on geomorphology and chemistry. In: Lateritization processes, Proceedings of International seminar on lateritization processes, December 1979. 0xford and IBH Publishing Company (New Delhi): 270-268.

Prasad, G., 1983. A review of the early Tertiary bauxite event in South America, Africa and India. Journal of African Earth Sciences 1 (3-4): 305-313.

Tardy, Y., 1997. Petrology of Laterites and Tropical Soils, translated by Sarma, V. A.A. Balkema (Rotterdam-Brookfield): 376 pp.

Tardy, Y, Kobilsek, B. \& Paquet, H., 1991. Mineralogical composition and geographic distribution of African and Brazilian periatlantic laterites. The influence of continental drift and tropical paleoclimates during the past 150 million years and implications for India and Australia. Journal of African Earth Sciences 12 (1-2): 283-295.

Théveniaut, H. \& Freyssinet, Ph., 2002. Timing of lateritization on the Guiana Shield: synthesis of paleomagnetic results from French Guiana and Suriname, Palaeography, Palaeoclimatology, Palaeoecology 178: 91-117.

Valeton, I., 1972. Bauxites. Elsevier (Amsterdam): 226 pp.

Valeton, I., 1983. Palaeoenvironment of lateritic bauxites with vertical and lateral differentiation. Geological Society, London, Special Publications 11: 77-90.

Van den Bergh, J., 2011. Executive summary for the Nassau Plateau bauxite project. Internal Suralco report: 1-14.

Van der Hammen, Th. \& Wijmstra, T.A., 1964. Palynological data on the age of the bauxite in British Guyana and Suriname. Geologie en Mijnbouw 43: 143.

Van Kersen, J., 1956. Bauxite deposits in Surinam and Demerara British Guiana. Leidse Geologische Mededelingen 21 (1): 247-375.

Wong, Th.E., 1989. Revision of the stratigraphy of the coastal plain of Suriname. Mededelingen Natuurwetenschappelijk Studiekring voor Suriname en de Nederlandse Antillen 123: 64. 
Wong, Th., Krook, L. \& Zonneveld, J., 1998. Investigations in the coastal plain and offshore area of Suriname. In: Wong, Th., de Vletter, D., Krook, L., Zonneveld,I. \& van Loon, A (eds.): The history of Earth Sciences in Suriname. Kon. Ned. Akad. Wetensch. Ned. Inst. Toegep. Geowet., TN0: 73-100.

Wong, Th.E., De Kramer, , De Boer, P, Langereis, C. \& Sew-A-Tjon, J., 2009. The influence of sea-level changes on tropical coastal lowlands; the Pleistocene Coropina formation, Suriname. Sedimentary Geology 216: 125-137.

\section{Websites}

www.alcoa.com (accessed 15 January 2014)

www.bauxietinstituut.com (accessed 20 0ctober 2014)

www.cbvs.sr (accessed 11 March 2015)

www.staatolie.com (accessed 17 December 2014) 